\title{
The human chorionic gonadotropin test is more powerful than the gonadotropin-releasing hormone agonist test to discriminate male isolated hypogonadotropic hypogonadism from constitutional delayed puberty
}

\author{
V Degros, C Cortet-Rudelli, B Soudan ${ }^{1}$ and D Dewailly \\ Service d'Endocrinologie et de Diabétologie and ${ }^{1}$ Laboratoire de Biochimie Endocrinienne et Périnatale, Clinique Marc Linquette, 6 , \\ rue du Professeur Laguesse, 59037 Lille cedex, France \\ (Correspondence should be addressed to V Degros; Email: ddewailly@chru-lille.fr)
}

\begin{abstract}
Objective: The effectiveness of biological investigations aiming at discriminating isolated hypogonadotropic hypogonadism (IHH) from constitutional delayed puberty (CDP) in male patients is still controversial. We revisited the diagnostic power of the basal serum testosterone level, the Triptorelin test and the human chorionic gonadotropin (hCG) test in a cohort of 33 boys with delayed puberty. Design: Boys were aged 14.2 to 26.2 years at referral. A 5-year-long clinical follow-up after the initial study allowed confirmation of the diagnosis. At the end of the follow-up period, IHH was found in 13 patients while the other 20 had normal spontaneous pubertal development (CDP).

Results: At referral, a basal morning testosterone level $>1.7 \mathrm{nmol} / \mathrm{l}$ was observed in $55 \%$ of patients with CDP exclusively (predictive positive value $(\mathrm{PPV})=100 \%$; predictive negative value $(\mathrm{PNV})=59 \%$. For CDP, the PPV of the LH peak $3 \mathrm{~h}$ after Triptorelin was $100 \%$ by setting the upper threshold at $14 \mathrm{IU} / \mathrm{l}$ and the PNV was $72 \%$. However, no lower threshold could discriminate IHH from CDP in the remaining patients with an LH peak $3 \mathrm{~h}$ after Triptorelin $<14 \mathrm{IU} / \mathrm{l}$. In CDP patients, the PPV of the serum testosterone increment after hCG stimulation $(\Delta \mathrm{T} / \mathrm{hCG})$ was $100 \%$ for values $>9 \mathrm{nmol} / \mathrm{l}(\mathrm{PNV}=72 \%)$. In IHH patients, the PPV of $\Delta \mathrm{T} / \mathrm{hCG}$ was $100 \%$ for values $<3 \mathrm{nmol} / \mathrm{l}(\mathrm{PNV}=82 \%)$. Only $29 \%$ of the studied population had a $\Delta \mathrm{T} / \mathrm{hCG}$ between these lower and upper thresholds and therefore could not have been classified initially.

Conclusions: (i) Dynamic testing for the diagnosis of delayed puberty is useful only when the basal testosterone level is lower than $1.7 \mathrm{nmol} / \mathrm{l}$; (ii) in that case, the hCG test has better discriminating power than the Triptorelin test and appears as the best cost-effective investigation. It prevents useless and expensive investigations in about one-half of CDP patients with a basal morning testosterone level lower than $1.7 \mathrm{nmol} / \mathrm{l}$.
\end{abstract}

European Journal of Endocrinology 149 23-29

\section{Introduction}

Delayed puberty (DP) is observed in as many as 3\% of boys in the general population (1). In most cases, it is due to constitutional delayed puberty (CDP), a benign condition which recovers spontaneously. In a few cases, however, DP reveals a more threatening hypothalamic or pituitary lesion or is due to a sporadic or a familial genetic hypogonadotropic hypogonadism $(\mathrm{HH})$. The diagnosis of $\mathrm{HH}$ is easy in the case of Kallmann's syndrome, or other complex syndromes such as Prader-Willi (2), Laurence-Moon or BardetBiedl (3) syndromes, and mutation in the Dax-1 (4) or leptin (5) genes. However, most $\mathrm{HH}$ cases are isolated
(IHH), without other endocrine, neurologic or malformation disturbances. Sporadic IHH can be due to either genetic or acquired abnormality. So far, genetic investigations have provided few explanations for IHH. No mutation in the gonadotropin-releasing hormone $(\mathrm{GnRH})$ gene has been found in men (6) in contrast to mice (7). Mutations in the luteinizing hormone (LH) $\beta$ subunit (8), follicle-stimulating hormone (FSH) $\beta$ subunit (9) and GnRH receptor (10-13) genes have been previously reported in only a few patients with sporadic IHH. Conversely, IHH can reveal a pituitary or supra-pituitary tumor where it is necessary to perform magnetic resonance imaging (MRI) for a precise diagnosis and early adequate treatment. 
At the time of referral, it is often difficult to distinguish boys with CDP from those with IHH. Both conditions present effectively with similar clinical and hormonal features. Only the demonstration of a complete and spontaneous recovery can distinguish CDP from IHH. It is therefore most important to design a cost-effective strategy for male DP. Many testing protocols have been investigated to address this issue, such as nocturnal sampling for LH $(1,14)$, urinary gonadotropin measurement $(15,16)$, plasma LH measurement by a highly sensitive immunofluorometric assay (17), GnRH agonist (GnRHa) stimulation test $(18-21)$ or a human chorionic gonadotropin (hCG) test $(22-26)$. So far no consensus has emerged about a single, reliable and easy test with acceptable sensitivity and specificity. In many studies reporting on these tests, CDP and other causes of DP, mainly $\mathrm{IHH}$, were clearly distinct when data were expressed as means. However, a significant overlap was frequently observed between the two situations, thus limiting the diagnostic power of the test for a given individual. Moreover, the certainty as to whether partial IHH could be excluded in every patient with CDP was not established in most of the previously published series. This requires a long follow-up of patients, which was not fulfilled in most of the studies.

In this study, we took advantage of our ability to follow-up a cohort of patients with CDP or IHH for more than 5 years. In all patients, initial testing included a GnRH analog test and an hCG test. We have chosen to compare these two tests because they do not require the patients to stay overnight or for several days in hospital. Also, they are the ones most studied in the literature, but few authors have compared these tests with each other (27) or with others (18).

\section{Materials and methods \\ Patients and initial work-up}

Thirty-three male Caucasian patients with DP, aged 14.2 to 26.2 years at the time of referral, were included in this study before androgen replacement therapy. All subjects were admitted to the Department of Endocrinology and Diabetology at the University of Lille. Patients having a pituitary deficiency other than hypogonadotropism were excluded from the study. A search for anosmia, measurement of testis volume, weight, height, pubertal development assessment and bone age determination (according to the Greulich and Pyle atlas (28)) were performed in all subjects.

An i.v. catheter was inserted, and samples were obtained for determination of basal morning $(0800 \mathrm{~h})$ testosterone, LH and FSH serum levels.

The GnRHa was administered as a single s.c. injection of $0.1 \mathrm{mg}$ Triptorelin (Ipsen-Biotech Laboratories, Paris, France). This GnRH analog has a longer plasma half-life than native GnRH with an elimination half-life more than $80 \mathrm{~min}$, which is about fivefold that of natural GnRH. Its metabolic clearance rate is about threefold less than that of natural GnRH (29). Blood samples for LH, FSH, testosterone and estradiol $\left(\mathrm{E}_{2}\right)$ determinations were then obtained 3, 6, 12 and $24 \mathrm{~h}$ after Triptorelin injection.

Five days later, hCG was given as a single $5000 \mathrm{IU}$ i.m. injection and the serum testosterone level was assayed on a venous blood sample drawn $72 \mathrm{~h}$ after the hCG injection.

This study was approved by the ethical committee of Lille University Hospital.

\section{Patient follow-up}

A 5-year-long clinical follow-up enabled confirmation of the diagnosis for all the patients. Normal pubertal development occurred in 20 patients, with testis volume and plasma testosterone levels spontaneously reaching adult values. They were then classified as having CDP. Conversely, the other 13 patients whose pubertal development did not progress or remained incomplete during the follow-up were classified as having IHH. During the follow-up of treated patients, serum testosterone was evaluated 2 or 4 weeks after the last hCG or testosterone i.m. injection respectively.

\section{Hormone assays}

Serum testosterone was determined by radioimmunoassay (Coat-A-Count Testosterone; Diagnostic Products Corporation, Los Angeles, CA, USA). The sensitivity was $0.17 \mathrm{nmol} / \mathrm{l}$. The intra-assay coefficients of variation were $10.8 \%$ and $4.7 \%$ when plasma testosterone levels were 0.7 and $3.5 \mathrm{nmol} / \mathrm{l}$ respectively. The interassay coefficients of variation were $11 \%$ and $6.4 \%$ when plasma testosterone levels were 2.6 and $9.2 \mathrm{nmol} / \mathrm{l}$ respectively.

The LH and FSH assays were carried out by a microparticle immunoassay (AxSYM; Abbott Laboratories, Abbott Park, IL, USA). The sensitivity of the LH and FSH assays were 0.5 and $0.4 \mathrm{IU} / \mathrm{l}$ respectively. The LH intra- and interassay coefficients of variation were $4.5 \%$ and $4.3 \%$ respectively for a $4.8 \mathrm{IU} / \mathrm{l}$ level. The FSH intra- and interassay coefficients of variation were $3.7 \%$ and $3.1 \%$ respectively for a $5.3 \mathrm{IU} / \mathrm{l}$ level.

\section{Statistical analyses}

Variables were compared between groups by the Mann-Whitney test. Results are expressed as means \pm S.D. The difference was considered significant when $P<0.05$.

Predictive positive values (PPV) and predictive negative values (PNV) of the serum LH threshold $3 \mathrm{~h}$ after Triptorelin injection and the difference between the serum testosterone level before and $72 \mathrm{~h}$ after the hCG 
injection $(\Delta \mathrm{T} / \mathrm{hCG})$ for CDP diagnosis were determined by the ratios: number of patients with CDP above the threshold/number of patients above the threshold and number of patients with $\mathrm{IHH}$ below the threshold/number of patients below the threshold respectively.

PPV and PNV of $\Delta \mathrm{T} / \mathrm{hCG}$ for $\mathrm{IHH}$ diagnosis were determined by the ratios: number of patients with IHH below the threshold/number of patients below the threshold and number of patients with CDP above the threshold/number of patients above the threshold respectively.

\section{Results}

\section{Clinical data}

Table 1 shows that patients with IHH were older at the time of referral, with a smaller growth delay, an older bone age, a higher body mass index (BMI) and a lower testis volume than patients with CDP. However, this last parameter overlapped with the CDP group greatly (Fig. 1A). Two patients with IHH had a testis volume $>4 \mathrm{ml}$ while it was $<4 \mathrm{ml}$ in seven patients with CDP.

Table 1 Clinical data in both groups (CDP and IHH). Values are expressed as means (S.D.).

\begin{tabular}{lccc}
\hline & CDP & IHH & $\boldsymbol{P}$ \\
\hline Age (years) & $15.31(0.99)$ & $19.9(3.32)$ & $<0.001$ \\
Height $(\mathrm{m})$ & $1.51(0.11)$ & $1.69(0.14)$ & $<0.01$ \\
BMl $\left(\mathrm{kg} / \mathrm{m}^{2}\right)$ & $19(4.46)$ & $23.14(3.92)$ & $<0.01$ \\
Bone age (years) & $12.6(1.8)$ & $14.3(0.5)$ & $<0.01$ \\
Testis volume $(\mathrm{ml})$ & $4.75(1.83)$ & $2.71(1.58)$ & $<0.01$ \\
Cryptorchidia $(n)$ & $2(1$ bilateral) & $8(4$ bilateral) & NA \\
Anosmia $(n)$ & 0 & 4 & NA \\
Ichthyosis $(n)$ & 0 & 1 & NA \\
\hline
\end{tabular}

NA, not applicable.
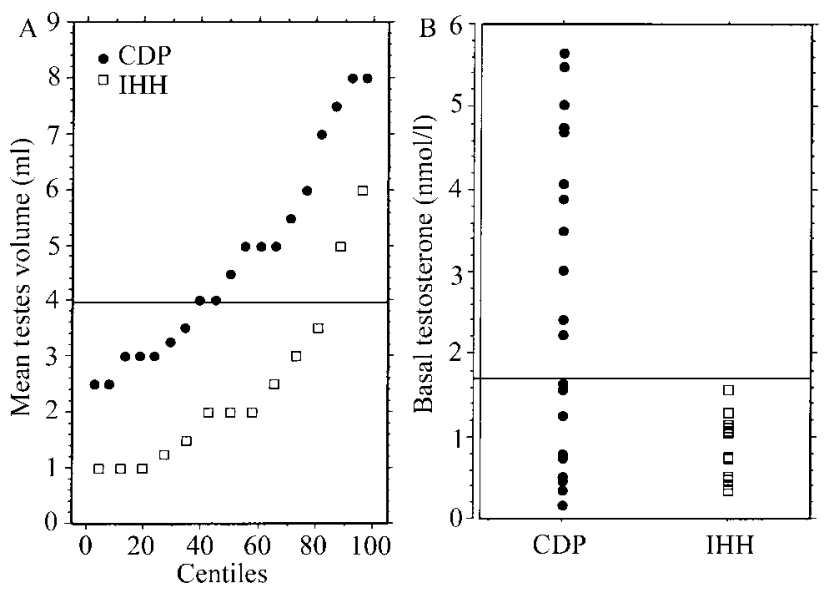

Figure $1(A)$ Individual values and centiles of testis volume in both groups. (B) Individual values of basal testosterone in both groups.
Anosmia was found in four unrelated patients, who were therefore considered as having sporadic Kallmann's syndrome.

\section{Baseline hormonal data}

LH and FSH serum levels were significantly higher in CDP than in IHH (Table 2). However, the range of individual values overlapped each other (Table 2). The mean basal morning serum testosterone level was significantly higher in CDP than in IHH (Table 2). Figure 1B shows that no individual value from the IHH group was $>1.7 \mathrm{nmol} / \mathrm{l}$. However, $50 \%$ of patients with CDP overlapped with the range of those with IHH.

\section{Triptorelin test}

As shown in Fig. 2, no difference was observed between $\mathrm{CDP}$ and $\mathrm{IHH}$ for serum levels of $\mathrm{E}_{2}$ at any time during the test. The mean FSH serum level peaked between 3 and $6 \mathrm{~h}$ after Triptorelin injection in both groups. A significant difference in the mean levels was observed only $24 \mathrm{~h}$ after injection (CDP vs IHH: 3.52 \pm 2.12 and $1.98 \pm 2.25 \mathrm{IU} / \mathrm{l}$ respectively, $P<0.05$ ), but no clearcut threshold could separate the two groups.

The serum LH level peaked $3 \mathrm{~h}$ after injection in both groups and was significantly higher in CDP than in $\mathrm{IHH}$ (18.4 \pm 9.4 vs $3.4 \pm 4.1 \mathrm{IU} / \mathrm{l}$ respectively, $P<0.001)$. It remained significantly higher at the later times of testing but the difference between the two groups was less. As shown in Fig. 3, a discriminating threshold could be set at $14 \mathrm{U} / \mathrm{l}$, since all patients with $\mathrm{IHH}$ were below this level while 14 out of the 19 patients with CDP were above. Therefore, the test yielded a $100 \%$ PPV and a $72 \%$ PNV for CDP. However, it left $56 \%$ of the patients from the total population unclassified.

The serum testosterone level increased slowly up to $24 \mathrm{~h}$ after injection in the CDP group while no significant increase was observed in patients with IHH. However, the individual $24 \mathrm{~h}$ serum testosterone level varied widely in the CDP group. No clear-cut threshold could therefore properly separate the two groups. The same conclusion was drawn when the difference between the 24-h and 0-h testosterone levels was used instead of the absolute 24-h testosterone level.

Table 2 Baseline hormone levels in both groups (CDP and IHH). Values are expressed as means (S.D.).

\begin{tabular}{lcrc}
\hline & CDP & IHH & $\boldsymbol{P}$ \\
\hline Testosterone $(\mathrm{nmol} / \mathrm{l})$ & $2.61(1.89)$ & $0.86(0.37)$ & $<0.05$ \\
DHAS $(\mu \mathrm{mol} / \mathrm{l})$ & $3.77(1.68)$ & $4.71(2.05)$ & NS \\
SHBG $(\mathrm{nmol} / \mathrm{l})$ & $69.98(37)$ & $60.77(32.4)$ & NS \\
FSH $(\mathrm{lu} / \mathrm{l})$ & $2.16(1.05)$ & $1.03(0.69)$ & $<0.01$ \\
LH $(\mathrm{lu} / \mathrm{l})$ & $1.67(1.87)$ & $0.53(0.25)$ & $<0.01$ \\
\hline
\end{tabular}

DHEAS, dehydroepiandrosterone sulfate; SHBG, sex hormone-binding globulin; NS, not significant. 



Figure 2 Responses after Triptorelin injection (0, 3, 6, 12 and $24 \mathrm{~h}$ ) of (A) LH, (B) FSH, (C) estradiol (E2) and (D) testosterone (T). Values are expressed as means \pm S.D. in both goups.

\section{hCG test}

The serum testosterone increment after hCG stimulation $(\Delta \mathrm{T} / \mathrm{hCG})$ was significantly higher in CDP than in $\mathrm{IHH}$ patients $(14.5 \pm 8.7 \mathrm{nmol} / \mathrm{l}$ vs $3.1 \pm 2.4 \mathrm{nmol} / \mathrm{l}$ respectively, $P<0.0001)$. Figure 4 shows the individual values for $\Delta \mathrm{T} / \mathrm{hCG}$. All patients with values $>9$ and $<3 \mathrm{nmol} / \mathrm{l}$ had CPD and IHH respectively. They represented $72 \%$ and $69 \%$ of the $\mathrm{CDP}$ and $\mathrm{IHH}$ groups respectively. The PPV and PNV for CDP diagnosis in the case of $\Delta \mathrm{T} / \mathrm{hCG}>9 \mathrm{nmol} / \mathrm{l}$ were $100 \%$ and $72 \%$ respectively. The PPV and PNV for $\mathrm{IHH}$ diagnosis in the case of $\Delta \mathrm{T} / \mathrm{hCG}<3 \mathrm{nmol} / \mathrm{l}$ were $100 \%$ and $82 \%$ respectively. Between 3 and $9 \mathrm{nmol} / \mathrm{l}$, four and five patients had CDP and $\mathrm{IHH}$ respectively (Fig. 4). These thresholds therefore left $29 \%$ of the patients from the total population unclassified. In this subset of patients, the 3-h LH level after Triptorelin did not discriminate since it was always $<14 \mathrm{U} / \mathrm{l}$.

\section{Discussion}

Some of our patients $(n=6)$ had overt $\mathrm{HH}$ at the time of referral (no pubertal signs at 20 years of age or more and/or evidence of Kallmann's syndrome). No difference in initial hormonal results was observed between these patients and those in whom the diagnosis of IHH could not be established at once (data not shown). They were therefore gathered up into a 




Figure 3 Individual values of $\mathrm{LH} 3 \mathrm{~h}$ after Triptorelin injection in both groups.

single group of patients with IHH in order to consolidate the comparison with patients with CDP, within the design of this study. We agree however that, in practice, such patients should not undergo any testing to distinguish them from CDP.

Our data confirm previous reports $(1,26,30)$ concluding that a basal testosterone level $>1.7 \mathrm{nmol} / \mathrm{l}$ has a good predictive value as a first screening test to discriminate idiopathic IHH from CDP. In patients with CDP, it means that puberty has spontaneously started, despite the absence of clinical evidence. Using this threshold would have prevented useless investigations in $55 \%$ of the CDP group and $33 \%$ of the total number of patients.

In patients with a basal testosterone level $<1.7 \mathrm{nmol} / \mathrm{l}$, further investigations are required. Priority should be given to those tests which yield optimal specificity and avoid missing the diagnosis of IHH. However, the tests should also have enough sensitivity to prevent the maximum number of patients with CDP from having useless investigations. In others studies, regardless of whether basal testosterone assay or tests were used, CDP and IHH were always clearly distinct when the data were expressed as means. However, the individual values from the two populations overlap almost constantly, except in a few studies. Morel et al. (15) found no overlap by using a urinary $\mathrm{FSH}$ test.

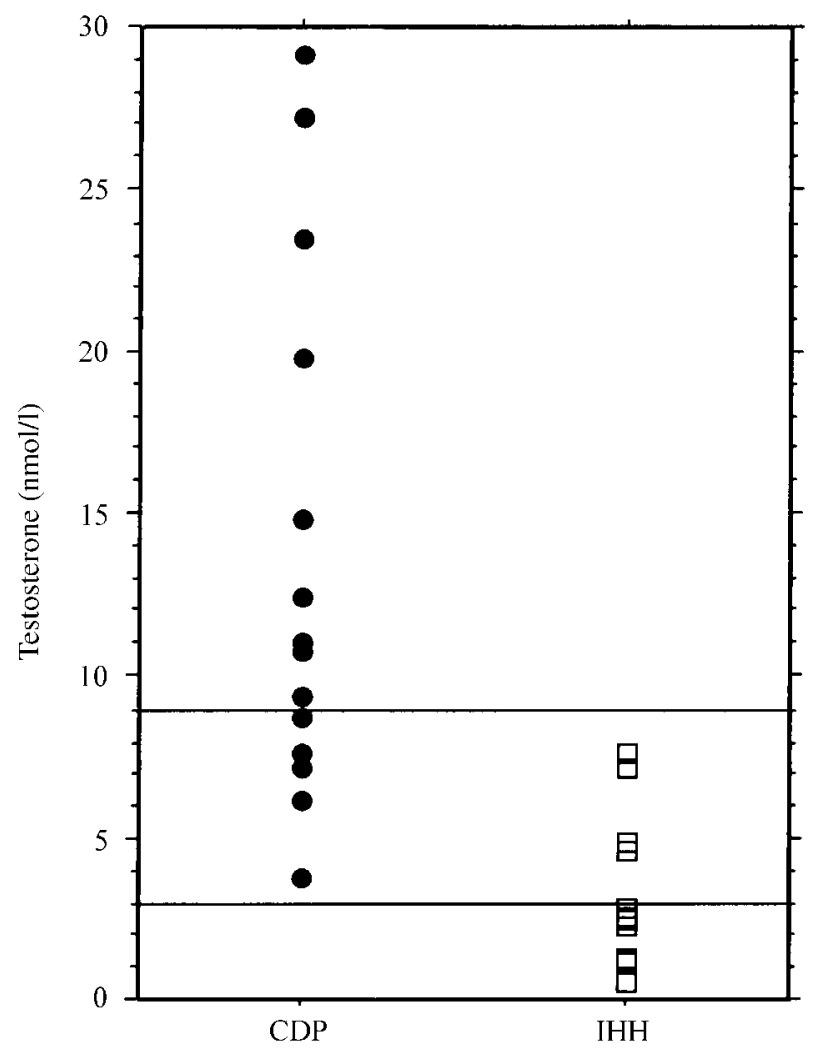

Figure 4 Individual values of $\Delta \mathrm{T} / \mathrm{hCG}$ (difference between serum testosterone at 0 and $72 \mathrm{~h}$ after the hCG injection) in both groups.

However, the two groups of patients were small (six with CDP and eight with IHH). In another study, Brown et al. (31) compared 42 prepubertal normal boys with 11 patients with idiopathic IHH or Kallmann's syndrome. No overlap was observed between these two groups when using the mean nocturnal LH plasma level (ultrasensitive assay). However, others have not confirmed the results of this study. In addition, this procedure is quite complicated and expensive, since it requires the patient to stay in hospital overnight.

In our hands, the Triptorelin test yielded unsatisfactory results. This confirms earlier studies with a different GnRHa (20, 32). It disagrees, however, with the studies of Zamboni et al. (21) and Kauschansky et al. (27). These authors were able to classify all their patients properly by using a cut-off threshold set at $8 \mathrm{U} / \mathrm{l}$ (27) or at about $10 \mathrm{U} / \mathrm{l}$ (21) for the LH serum level $4 \mathrm{~h}$ after a $0.1 \mathrm{mg} / \mathrm{m}^{2}$ Triptorelin s.c. injection. In these studies, CDP was ascertained by the spontaneous occurrence of pubertal signs only 1 year after the initial investigation. These discrepancies with regard to the diagnostic power of the GnRHa test can thus be explained by: (i) varying etiologies of $\mathrm{IHH}$ among the different series, (ii) selection of more or less severe cases of CDP, (iii) differences in the sensitivity of the LH assays and (iv) differences between the nature and route of administration of the GnRHa. 
In our study, the superiority of the hCG test over the Triptorelin test relied upon the ability to define a lower and an upper threshold for the level of testosterone, below and above which patients with IHH and CDP were properly assigned $(\mathrm{PPV}=100 \%)$ respectively. The upper threshold for $\Delta \mathrm{T} / \mathrm{hCG}$ at $9 \mathrm{nmol} / \mathrm{l}$ is close to the one set by others at $7 \mathrm{nmol} / \mathrm{l}$, with a different protocol of hCG injections (26).

In a previous study (27), no overlap in the testosterone response to hCG was observed between the two groups using a cut-off level at $8 \mathrm{nmol} / \mathrm{l}$. However, this study used a different protocol (1500 U injected i.m. on 3 alternate days and blood samples for testosterone determination drawn on day 7). In addition, the pubertal stage was reassessed only 1 year after the initial referral. One cannot exclude, therefore, that in this series some cases of CDP were mixed up with patients having IHH.

The hCG test in the management of male DP is reliable, cheap, easy and comfortable for the patients (no hospitalization needed). According to our diagnosis strategy illustrated in Fig. 5, patients with basal testosterone $<1.7 \mathrm{nmol} / \mathrm{l}$ and $\Delta \mathrm{T} / \mathrm{hCG}<9 \mathrm{nmol} / \mathrm{l}$ must have an MRI investigation because it can reveal a pituitary or supra-pituitary tumor in patients with IHH. When there is evidence for Kallmann's syndrome (anosmia and/or family history), MRI is of no use since finding of olfactory bulb aplasia (33) would not change the management of the hypogonadism. For the moment, the majority of cases of IHH with normal MRI corresponds with idiopathic IHH for which hormonal investigations are still mandatory. Whether genetic studies will modify this strategy in the future remains so far speculative.

In conclusion, dynamic testing for the diagnosis of DP is useful only when the basal testosterone level is lower than $1.7 \mathrm{nmol} / \mathrm{l}$. In that case, the hCG test offers the best cost-effective investigation, with a better discriminating power than the Triptorelin test. It saves useless and expensive investigations in about

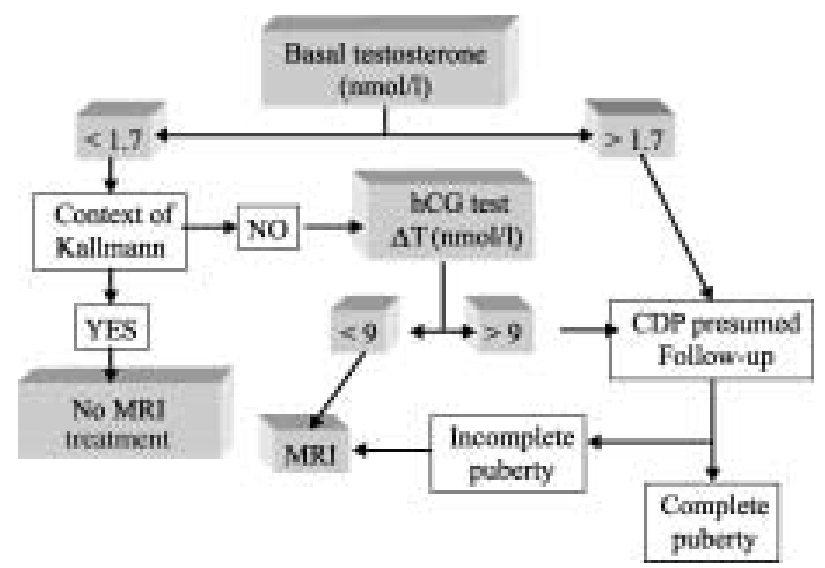

Figure 5 Diagnostic strategy for the management of DP in males. half of the CDP patients in whom the basal testosterone level is lower than $1.7 \mathrm{nmol} / \mathrm{l}$. This has a non-negligible medical and psychological impact on the patient and his family.

\section{References}

1 Rosenfield RL. Clinical review 6. Diagnosis and management of delayed puberty. Journal of Clinical Endocrinology and Metabolism $199070559-562$.

2 Holm VA, Cassidy SB, Butler MG, Hanchett JM, Greenswag LR, Whitman BY et al. Prader-Willi syndrome: consensus diagnostic criteria. Pediatrics 199391 398-402.

3 Green JS, Parfrey PS, Harnett JD, Farid NR, Cramer BC, Johnson G et al. The cardinal manifestations of Bardet-Biedl syndrome. A form of Laurence-Moon-Biedl syndrome. New England Journal of Medicine $19893211002-1009$.

4 Habiby RL, Boepple P, Nachtigall L, Sluss PM, Crowley WF \& Jameson JL. Adrenal hypoplasia congenital with hypogonadotropic hypogonadism. Evidence that DAX-1 mutations lead to combined hypothalamic and pituitary defects in gonadotropin production. Journal of Clinical Investigation 199698 1055-1062.

5 Strobel A, Issad T, Camoin L, Ozata M \& Strosberg AD. A leptin missense mutation associated with hypogonadism and morbid obesity. Nature Genetics 199818 213-215.

6 Weiss J, Crowley WF Jr \& Jameson JL. Normal structure of the gonadotropin-releasing hormone $(\mathrm{GnRH})$ gene in patients with GnRH deficiency and idiopathic hypogonadotropic hypogonadism. Journal of Clinical Endocrinology and Metabolism 198969 299-303.

7 Mason AJ, Pitts SL, Nikolics D, Szongi E, Wilcox JN, Seeburg PH et al. The hypogonal mouse reproductive functions restored by gene therapy. Science $1986 \mathbf{2 3 4} 1372-1378$.

8 Weiss J, Axelrod L, Withcomb RW, Harris PE, Crowley WF \& Jameson JL. Hypogonadism caused by a single amino acid substitution in the $\beta$ subunit of luteinizing hormone. New England Journal of Medicine 1992326 179-183.

9 Phillip M, Arbelle JE, Segeo Y \& Parvari R. Male hypogonadism due to a mutation in the gene of $\beta$-subunit of follicle-stimulating hormone. New England Journal of Medicine $1998 \mathbf{3 3 8}$ $1729-1732$.

10 De Roux N, Young J, Misrahi M, Genet R, Chanson P, Schaison G et al. A family with hypogonadotropic hypogonadism and mutation in the gonadotropin-releasing hormone receptor. New England Journal of Medicine 1997337 1597-1602.

11 De Roux N, Young J, Brailly-Tabard S, Misrahi M, Milgrom E \& Schaison G. The same molecular defects of the GnRH receptor determine a variable degree of hypogonadism in affected kindred. Journal of Clinical Endocrinology and Metabolism $1999 \mathbf{8 4}$ 567-572.

12 Layman LC, Cohen DP, Jim M, Xie J, Li Z, Reindollar RH et al. Mutation in GnRH receptor gene causes hypogonadotropic hypogonadism. Nature Genetics $1998 \mathbf{1 8} 14-15$.

13 Caron P, Chauvin S, Christin-Maitre S, Bennet A, Lahlou N, Counis R et al. Resistance of hypogonadic patients with mutated GnRH receptor genes to pulsatile GnRH administration. Journal of Clinical Endocrinology and Metabolism $1999 \mathbf{8 4}$ 990-996.

14 Odink RJ, Schoemaker J, Schoute E, Herdes E \& Delemarre-van de Waal HA. Predictive value of serum follicle-stimulating hormone levels in the differentiation between hypogonadotropic hypogonadism and constitutional delay of puberty. Hormone Research $199849279-287$.

15 Morel Y, La Selve H, Chatelain P, Perez J, Varenne JP, De Peretti E et al. Intérêt du dosage des gonadotrophines urinaires en endocrinologie pédiatrique. Archives Françaises de Pédiatrie $198542579-585$.

16 Kulin H, Demers L, Chinchilli V, Martel J \& Stevens L. Usefulness of sequential urinary follicle-stimulating hormone and luteinizing 
hormone measurements in the diagnosis of adolescent hypogonadotropism in males. Journal of Clinical Endocrinology and Metabolism 199478 1208-1211.

17 Haavisto AM, Dunkel L, Petersson K \& Huhtaniemi I. LH measurements by in vitro bioassay and a highly sensitive immunofluorometric assay improve the distinction between boys with constitutional delay of puberty and hypogonadotropic hypogonadism. Pediatric Research 199027 211-214.

18 Ghai K, Cara JF \& Rosenfield RL. Gonadotropin releasing hormone agonist (Nafarelin) test to differentiate gonadotropin deficiency from constitutional delayed puberty in teen-age boys. A clinical research center study. Journal of Clinical Endocrinology and Metabolism $1995 \mathbf{8 0}$ 2980-2986.

19 Cuttler L, Rosenfield RL, Ehrmann DA, Kreiter M, Burstein S, Cara JF et al. Maturation of gonadotropin and sex steroid responses to gonadotropin-releasing hormone agonist in males. Journal of Clinical Endocrinology and Metabolism $1993 \mathbf{7 6}$ 362-366.

20 Ehrmann DA, Rosenfield RL, Cuttler L, Burstein S, Cara JF \& Levitsky LL. A new test of combined pituitary-testicular function using the gonadotropin-releasing hormone agonist Nafarelin in the differentiation of gonadotropin deficiency from delayed puberty: pilot studies. Journal of Clinical Endocrinology and Metabolism 198969 963-967.

21 Zamboni G, Antoniazzi F \& Tato L. Use of the gonadotropin-releasing hormone agonist Triptorelin in the diagnosis of delayed puberty in boys. Journal of Pediatrics 1995126 756-758.

22 Dunkel L, Perheentupa J \& Apter D. Kinetics of the steroidogenic response to single versus repeated doses of human chorionic gonadotropin in boys in prepuberty and early puberty. Pediatric Research $1985191-4$.

23 Dunkel L, Perheentupa J \& Sorva R. Single versus repeated dose human chorionic gonadotropin stimulation in the differential diagnosis of hypogonadotropic hypogonadism. Journal of Clinical Endocrinology and Metabolism $198560333-337$.

24 Dunkel L, Perheentupa J, Virtanen M \& Maenpaa J. GnRH and hCG tests are both necessary in differential diagnosis of male delayed puberty. American Journal of Diseases of Children 1985 $139494-498$.
25 Bardin CW, Ross GT, Rifkind AB, Cargille CM \& Lipsett MB. Studies of the pituitary-Leydig cell axis in young men with hypogonadotropic hypogonadism and hyposmia: comparison with normal men, prepubertal boys, and hypopituitary patients. Journal of Clinical Investigation 196948 2046-2056.

26 Forest MG, Morel Y \& David M. Diagnostic et traitement de l'insuffisance gonadotrope chez l'adolescent. Annales d'Endocrinologie $198546269-270$.

27 Kauschansky A, Dickerman Z, Phillip M, Weintrob N \& Strich D. Use of GnRH agonist and human chorionic gonadotrophin tests for differentiating constitutional delayed puberty from gonadotrophin deficiency in boys. Clinical Endocrinology $2002 \mathbf{5 6}$ 603-607.

28 Grevlich WW \& Pyle SI. Atlas of skeletal development of the hand and wrist, edn 2. Stanford: Standard University Press, 1955.

29 Barron JL, Millar RP \& Searle D. Metabolic clearance and plasma half-disappearance time of D-TRP6 and exogenous luteinizing hormone-releasing hormone. Journal of Clinical Endocrinology and Metabolism $1982 \mathbf{5 4} 1169-1173$.

30 Wu FCW, Brown DC, Butler GE, Stirling HF \& Kelnar CJH. Early morning plasma testosterone is an accurate predictor of imminent pubertal development in prepubertal boys. Journal of Clinical Endocrinology and Metabolism 199376 26-31.

31 Brown DC, Stirling HF, Butler GE, Kelnar CJH \& Wu FCW. Differentiation of normal male prepuberty and hypogonadotrophic hypogonadism using an ultrasensitive luteinizing hormone assay. Hormone Research 199646 83-87.

32 Lanes R, Gunczler P, Osuna JA, Palacios A, Carrillo E, Ramirez X et al. Effectiveness and limitation of the use of the gonadotropinreleasing hormone agonist leuprolide acetate in the diagnosis of delayed puberty in males. Hormone Research $1997 \mathbf{4 8} 1-4$.

33 Vogl TJ, Stemmmler J, Heye B, Schopohl J, Danek A, Bergman C et al. Kallman syndrome versus idiopathic hypogonadotropic hypogonadism at MR imaging. Radiology $199419153-57$.

Received 17 January 2003

Accepted 23 April 2003 